\title{
Spectroscopic characterization of a coumarin-labelled therapeutic tetrapeptide
}

\author{
Filipa C. Santos, M. Sameiro T. Gonçalves, Susana P. G. Costa \\ Department of Chemistry, University of Minho, Campus of Gualtar, 4710-057 - Braga Portugal \\ spc@quimica.uminho.pt
}

\begin{abstract}
The present work describes the synthesis of the tetrapeptide H-Ala-Ala-Pro-Val- $\mathrm{NH}_{2}$ (AAPV), an important inhibitor of the enzyme human neutrophil elastase, labelled at the $C$-terminus with a 7-methoxycoumarinyl moiety. Photophysical studies were made with spectroscopic characterization by UV-vis and fluorescence spectroscopy in different organic solvents and mixtures with aqueous HEPES solution, in order to simulate physiological conditions.
\end{abstract}

Keywords: Tetrapeptide AAPV; Coumarin; UV-visible spectroscopy; Fluorescent labelling.

\section{Introduction}

Coumarins (the trivial designation of 3-oxo-3H-benzopyrans) are an important family of compounds that have been reported as fluorescent labels and probes [1]. Coumarins are well known fluorophores with an extended spectral range, high fluorescence quantum yields, good photostability and solubility in common solvents [1-3]. As most amino acids are poor UV-absorbing, fluorescence labelling is often employed in peptides and, for example, a peptide or protein bound to a fluorescent moiety may be an important tool for conformational studies of protein-protein and ligand-receptor interactions. Coumarins have also been applied in the synthesis of photolabile protecting groups to release relevant biomolecules by UV and visible light irradiation $[4,5]$ and can thus be used in the preparation of photoactive prodrugs.

The tetrapeptide H-Ala-Ala-Pro-Val- $\mathrm{NH}_{2}$ (AAPV) is an important inhibitor of the enzyme human neutrophil elastase, $\mathrm{HNE}$ ), which is present in high levels in a variety of inflammatory disorders, such as psoriasis. The inhibition of HNE by this hydrophobic sequence occurs when the peptide fits the P$\mathrm{P}_{1}$ subsites of elastase and competitively inhibits HNE [6,7]. Some studies have been conducted for the use of this peptide as a therapeutic agent for transdermal delivery [6]. Therefore, in the present communication the tetrapeptide AAPV was synthesized by the stepwise coupling of the corresponding amino acids in solution and labelled at the $C$-terminus with a 7 -methoxycoumarinyl moiety. This peptide conjugate was submitted to photophysical studies for its spectroscopic characterization by UV-vis and fluorescence spectroscopy in different organic solvents and mixtures with aqueous HEPES solution, in order to simulate physiological conditions. 


\section{Experimental}

\section{Synthesis of 4-chloromethyl-7-methoxycoumarin}

3-Methoxyphenol ( $\left.0.25 \mathrm{~g}, 2.0 \times 10^{-3} \mathrm{~mol}\right)$ was mixed with ethyl 4-chloro-3-oxobutanoate (1.5 eq, 0.42 $\left.\mathrm{mL}, 3.0 \times 10^{-3} \mathrm{~mol}\right)$ at room temperature and aqueous sulphuric acid $70 \%(5 \mathrm{~mL})$ was added. The reaction mixture was stirred at room temperature for 24 hours. The mixture was poured into ice, the formed precipitate was filtered, washed with water and dried in the oven at $50{ }^{\circ} \mathrm{C}$. The resulting solid was purified by recrystallization using methanol/diethyl ether. The pure compound was obtained as a greyish solid (0.195 g, 43\%). ${ }^{1} \mathrm{H}$ NMR $\left(400 \mathrm{MHz}, \mathrm{CDCl}_{3}\right): \delta=3.89\left(3 \mathrm{H}, \mathrm{s}, \mathrm{OCH}_{3}\right), 4.63(2 \mathrm{H}, \mathrm{d}, J 0.8$ $\left.\mathrm{Hz}, \mathrm{CH}_{2}\right), 6.41(1 \mathrm{H}, \mathrm{s}, \mathrm{H}-3), 6.86(1 \mathrm{H}, \mathrm{d}, J 2.4 \mathrm{~Hz}, \mathrm{H}-8), 6.91(1 \mathrm{H}, \mathrm{dd}, J 8.8$ and $2.4 \mathrm{~Hz}, \mathrm{H}-6), 7.56$ $(1 \mathrm{H}, \mathrm{d}, J 8.8 \mathrm{~Hz}, \mathrm{H}-5)$.

\section{Synthesis of the peptide AAPV labeled with coumarin}

\subsection{Coupling of coumarin to the $C$-terminal amino acid and deprotection}

4-Chloromethyl-7-methoxycoumarin $\left(0.1557 \mathrm{~g}, 6.90 \times 10^{-4} \mathrm{~mol}\right)$ was dissolved in dry dimehtylformamide $(2 \mathrm{~mL})$, potassium fluoride $\left(0.1203 \mathrm{~g}, 2.1 \times 10^{-3} \mathrm{~mol}, 3 \mathrm{eq}\right)$ and the $C$-terminal protected amino acid $\mathrm{N}$-tert-butyloxycarbonyl-L-valine (Boc-Val-OH) $\left(0.150 \mathrm{~g}, 6.90 \times 10^{-4} \mathrm{~mol}, 1 \mathrm{eq}\right)$ were added. The reaction mixture was stirred at room temperature for 4 days. Potassium fluoride was filtered and the solvent was removed by rotary evaporation. The residue obtained was an orange solid (0.246 g, 87\%). ${ }^{1} \mathrm{H}$ NMR (400 MHz, $\left.\mathrm{CDCl}_{3}\right): \delta=0.89\left(3 \mathrm{H}, \mathrm{d}, J 6.8 \mathrm{~Hz}, \mathrm{CH}_{3}\right.$ Val), $0.97(3 \mathrm{H}, \mathrm{d}, J 6.8 \mathrm{~Hz}$, $\mathrm{CH}_{3}$ Val), $1.43(9 \mathrm{H}, \mathrm{s}, \mathrm{Boc}), 2.12-2.17\left(1 \mathrm{H}, \mathrm{m}, \beta-\mathrm{CH}\right.$ Val), $3.86\left(3 \mathrm{H}, \mathrm{s}, \mathrm{OCH}_{3}\right), 5.05(1 \mathrm{H}, \mathrm{d}, J 8.4 \mathrm{~Hz}, \alpha-$ $\mathrm{CH}$ Val), 5.24-5.33 (2H, m, CH$)_{2}, 6.33(1 \mathrm{H}, \mathrm{d}, J 1.2 \mathrm{~Hz}, \mathrm{H}-3), 6.82-6.86(2 \mathrm{H}, \mathrm{m}, \mathrm{H}-6$ and H-8), 7.40 $(1 \mathrm{H}, \mathrm{d}, J 8.8 \mathrm{~Hz}, \mathrm{H}-5), 8.88(1 \mathrm{H}, \mathrm{s}, \mathrm{NH})$.

The $\mathrm{N}$-protecting group of the obtained valine-coumarin conjugate $\left(0.246 \mathrm{~g}, 6.08 \times 10^{-4} \mathrm{~mol}\right)$ was cleaved with trifluoroacetic acid $\left(2.05 \mathrm{~mL}, 6.08 \times 10^{-4} \mathrm{~mol}\right)$ in dichloromethane $(4 \mathrm{~mL})$ at room temperature for 1 hour. The solvents were evaporated and the residue was treated with diethyl ether $(5 \mathrm{~mL})$ yielding a yellow solid $\left(0.2312 \mathrm{~g}\right.$, quantitative yield). ${ }^{1} \mathrm{H} \mathrm{NMR}\left(400 \mathrm{MHz}, \mathrm{CDCl}_{3}\right): \delta=1.19(6 \mathrm{H}$, $\mathrm{m}, 2 \times \mathrm{CH}_{3}$ Val), 2.51-2.54 (1H, m, $\beta-\mathrm{CH}$ Val), $3.89\left(3 \mathrm{H}, \mathrm{s}, \mathrm{OCH}_{3}\right), 5.27-5.34\left(2 \mathrm{H}, \mathrm{m}, \mathrm{CH}_{2}\right), 5.50-5-53$ $(1 \mathrm{H}, \mathrm{m}, \mathrm{\alpha}-\mathrm{CH}$ Val), $6.66(1 \mathrm{H}, \mathrm{s}, \mathrm{H}-3), 6.85(1 \mathrm{H}, \mathrm{d}, J 2.0 \mathrm{~Hz}, \mathrm{H}-8), 6.90(1 \mathrm{H}, \mathrm{dd}, J 8.8$ and $2.8 \mathrm{~Hz}, \mathrm{H}-6)$, $7.40(1 \mathrm{H}, \mathrm{d}, J 8.8 \mathrm{~Hz}, \mathrm{H}-5)$.

\subsection{Coupling to Boc-Pro-OH and deprotection of the dipeptide}

$N$-tert-butyloxycarbonyl-L-proline (Boc-Pro-OH) $\left(0.163 \mathrm{~g}, 7.57 \times 10^{-4} \mathrm{~mol}\right)$ was dissolved in acetonitrile (10 mL), 1-hydroxybenzotriazole (HOBt) $\left(0.1023 \mathrm{~g}, 7.57 \times 10^{-4} \mathrm{~mol}, 1 \mathrm{eq}\right)$ was added and the reaction mixture was stirred at room temperature for 30 minutes. Then $N, N^{\prime}$-dicyclohexylcarbodiimide (DCC) $\left(0.1562 \mathrm{~g}, 7.57 \times 10^{-4} \mathrm{~mol}, 1 \mathrm{eq}\right)$ was added and the mixture was stirred at room temperature for 2 hours. Separately, the previously synthesized valine-coumarin conjugate $\left(0.2312 \mathrm{~g}, 7.57 \times 10^{-4} \mathrm{~mol}\right)$ was dissolved in acetonitrile $(5 \mathrm{~mL})$ and then added to the reaction mixture containing Boc-Pro-OH and the mixture heated at reflux for 20 hours. The formed solid (the corresponding urea) was filtered and the solvent was evaporated in a rotary evaporator. The residue was dissolved in ethyl acetate (25 
$\mathrm{mL}$ ) and extracted with hydrochloric acid $1 \mathrm{M}(25 \mathrm{~mL})$ and then with sodium hydrogencarbonate $10 \%$ $(25 \mathrm{~mL})$. Anhydrous magnesium sulphate was added to the organic layer, filtered and the solvent was evaporated under reduced pressure. The dipeptide-coumarin conjugate obtained was an orange oil (0.2417 g, 64\%). ${ }^{1} \mathrm{H}$ NMR (400 MHz, $\left.\mathrm{CDCl}_{3}\right): \delta=0.88-0.94$ (6H, m, $2 \times \mathrm{CH}_{3}$ Val), 1.41 (9H, s, Boc), 1.43-1.47 (2H, m, $\mathrm{CH}_{2}$ Pro), 1.87-1.90 (2H, m, $\mathrm{CH}_{2}$ Pro), 1.95-2.03 (1H, m, $\beta-\mathrm{CH}$ Val), 3.41-3.45 (2H, m, $\mathrm{CH}_{2}$ Pro), $3.84\left(3 \mathrm{H}, \mathrm{s}, \mathrm{OCH}_{3}\right), 4.30-4.36(1 \mathrm{H}, \mathrm{m}, \alpha-\mathrm{CH}$ Val), 4.47-4.53 $(1 \mathrm{H}, \mathrm{m}, \alpha-\mathrm{CH}$ Pro), 5.25$5.31\left(2 \mathrm{H}, \mathrm{m}, \mathrm{CH}_{2}\right), 6.33(1 \mathrm{H}, \mathrm{s}, \mathrm{H}-3), 6.80(1 \mathrm{H}, \mathrm{s}, \mathrm{H}-8), 6.83(1 \mathrm{H}, \mathrm{dd}, J 8.8$ and $2.0 \mathrm{~Hz}, \mathrm{H}-6), 7.39(1 \mathrm{H}$, d, J $9.2 \mathrm{~Hz}, \mathrm{H}-5)$.

The $N$-protecting group of the obtained dipeptide-coumarin conjugate $\left(0.2417 \mathrm{~g}, 4.81 \times 10^{-4} \mathrm{~mol}\right)$ was cleaved with trifluoroacetic acid $\left(1.62 \mathrm{~mL}, 4.81 \times 10^{-4} \mathrm{~mol}\right)$ in dichloromethane $(4 \mathrm{~mL})$ at room temperature for 1 hour. The solvents were evaporated and the residue was treated with diethyl ether $(5 \mathrm{~mL})$ yielding a yellow solid $(0.1207 \mathrm{~g}, 63 \%) .{ }^{1} \mathrm{H}$ NMR $\left(400 \mathrm{MHz}, \mathrm{CDCl}_{3}\right): \delta=0.97-1.00(6 \mathrm{H}, \mathrm{m}, 2 \mathrm{x}$ $\mathrm{CH}_{3} \mathrm{Val}$ ), 1.98-2.30 (4H, m, $2 \times \mathrm{CH}_{2}$ Pro), 2.45-2.50 (1H, m, $\beta-\mathrm{CH}$ Val), 3.45-3.50 (2H, m, $\mathrm{CH}_{2}$ Pro), $3.88\left(3 \mathrm{H}, \mathrm{s}, \mathrm{OCH}_{3}\right), 4.47-4.50(1 \mathrm{H}, \mathrm{m}, \alpha-\mathrm{CH}$ Pro $), 4.86-4.90(1 \mathrm{H}, \mathrm{m}, \alpha-\mathrm{CH}$ Val $), 5.30-5.33(2 \mathrm{H}, \mathrm{m}$, $\left.\mathrm{CH}_{2}\right), 6.37(1 \mathrm{H}, \mathrm{s}, \mathrm{H}-3), 6.83(1 \mathrm{H}, \mathrm{d}, J 2.4 \mathrm{~Hz}, \mathrm{H}-8), 6.88(1 \mathrm{H}$, dd, J 8.8 and $2.4 \mathrm{~Hz}, \mathrm{H}-6), 7.39(1 \mathrm{H}, \mathrm{d}$, $J 8.8 \mathrm{~Hz}, \mathrm{H}-5), 8.12(1 \mathrm{H}, \mathrm{d}, J 7.2 \mathrm{~Hz}, \mathrm{NH}-\mathrm{Val})$.

\subsection{Coupling to Boc-Ala-OH and deprotection of the tripeptide}

$\mathrm{N}$-tert-butyloxycarbonyl-L-alanine (Boc-Ala-OH) $\left(0.057 \mathrm{~g}, 3.01 \times 10^{-4} \mathrm{~mol}\right)$ was dissolved in acetonitrile $(10 \mathrm{~mL})$, HOBt $\left(0.041 \mathrm{~g}, 3.01 \times 10^{-4} \mathrm{~mol}, 1 \mathrm{eq}\right)$ was added and the reaction mixture was stirred at room temperature for 30 minutes. Then DCC $\left(0.062 \mathrm{~g}, 3.01 \times 10^{-4} \mathrm{~mol}, 1 \mathrm{eq}\right)$ was added and the mixture was stirred at room temperature for 2 hours. Separately, the previously synthesized dipeptidecoumarin conjugate $\left(0.1207 \mathrm{~g}, 3.01 \times 10^{-4} \mathrm{~mol}\right)$ was dissolved in acetonitrile $(5 \mathrm{~mL})$ and added to the reaction mixture containing Boc-Ala-OH and heated at reflux for 20 hours. The formed solid was filtered and the solvent was evaporated in a rotary evaporator. The residue was dissolved in ethyl acetate $(25 \mathrm{~mL})$ and extracted with hydrochloric acid $1 \mathrm{M}(25 \mathrm{~mL})$ and then with sodium hydrogencarbonate $10 \%(25 \mathrm{~mL})$. Anhydrous magnesium sulphate was added to the organic layer, filtered and the solvent was evaporated under reduced pressure. The crude tripeptide-coumarin conjugate was obtained as an orange oil $(0.069 \mathrm{~g}, 40 \%)$. ${ }^{1} \mathrm{H} \mathrm{NMR}\left(400 \mathrm{MHz}, \mathrm{CDCl}_{3}\right): \delta=0.86-0.90$ (6H, m, $2 \times \mathrm{CH}_{3}$ Val), 1.31 (9H, s, Boc), 1.39 (3H, d, J $\left.6.0 \mathrm{~Hz}, \mathrm{CH}_{3} \mathrm{Ala}\right), 1.85-1.90$ (2H, m, CH $\mathrm{CH}_{2}$ Pro), 1.98-2.02 (2H, m, CH $\mathrm{CH}_{2}$ Pro), 2.05-2.11 (1H, $\mathrm{m}, \beta-\mathrm{CH}$ Val), 3.41-3.46 (2H, m, $\mathrm{CH}_{2}$ Pro), $3.84(3 \mathrm{H}, \mathrm{s}$, $\left.\mathrm{OCH}_{3}\right), 4.45-4.48(2 \mathrm{H}, \mathrm{m}, \alpha-\mathrm{CH}$ Val and $\alpha-\mathrm{CH}$ Ala), 4.54-4.59 (1H, m, $\alpha-\mathrm{CH}$ Pro), 5.22-5.29 (2H, m, $\left.\mathrm{CH}_{2}\right), 5.48(1 \mathrm{H}, \mathrm{d}, J 8.4 \mathrm{~Hz}, \mathrm{NH} \mathrm{Ala}), 6.37(1 \mathrm{H}, \mathrm{s}, \mathrm{H}-3), 6.80-6.85(2 \mathrm{H}, \mathrm{m}, \mathrm{H}-6$ and $\mathrm{H}-8), 7.38(1 \mathrm{H}, \mathrm{d}, J$ $8.4 \mathrm{~Hz}, \mathrm{H}-5), 7.57(1 \mathrm{H}, \mathrm{d}, J 8.0 \mathrm{~Hz}, \mathrm{NH}-\mathrm{Val})$.

The $N$-protecting group of the obtained tripeptide-coumarin conjugate $\left(0.115 \mathrm{~g}, 2.00 \times 10^{-4} \mathrm{~mol}\right)$ was cleaved with trifluoroacetic acid $\left(0.667 \mathrm{~mL}, 2.00 \times 10^{-4} \mathrm{~mol}\right)$ in dichloromethane $(2 \mathrm{~mL})$ at room temperature for 1 hour. The solvents were evaporated and the residue was treated with diethyl ether $(5 \mathrm{~mL})$ yielding a yellow solid (0.0756 g, quantitative yield). ${ }^{1} \mathrm{H} \mathrm{NMR}\left(400 \mathrm{MHz}, \mathrm{CDCl}_{3}\right): \delta=0.90-0.95$ $\left(6 \mathrm{H}, \mathrm{m}, 2 \times \mathrm{CH}_{3}\right.$ Val), $1.57\left(3 \mathrm{H}, \mathrm{d}, J 6.0 \mathrm{~Hz}, \mathrm{CH}_{3} \mathrm{Ala}\right), 1.83-2.00\left(4 \mathrm{H}, \mathrm{m}, 2 \times \mathrm{CH}_{2}\right.$ Pro), 2.18-2.21 (1H, $\mathrm{m}, \beta-\mathrm{CH}$ Val), 3.46-3.50 (2H, m, $\left.\mathrm{CH}_{2} \mathrm{Pro}\right), 3.88\left(3 \mathrm{H}, \mathrm{s}, \mathrm{OCH}_{3}\right), 4.31-4.33(1 \mathrm{H}, \mathrm{m}, \alpha-\mathrm{CH}$ Val), 4.51-4.54 
(1H, m, $\alpha-C H$ Pro), 4.70-4.74 (1H, s, $\alpha-C H$ Ala), 5.26-5.35 (2H, m, $\left.\mathrm{CH}_{2}\right), 6.45$ (1H, s, H-3), 6.82-6.89 (2H, m, H-6 and H-8), 7.40 (1H, d, J $8.8 \mathrm{~Hz}, \mathrm{H}-5), 7.59$ (1H, d, J $8.4 \mathrm{~Hz}, \mathrm{NH}-\mathrm{Val})$.

\subsection{Coupling to Boc-Ala-OH and isolation of the tetrapeptide}

Boc-Ala-OH $\left(0.028 \mathrm{~g}, 1.46 \times 10^{-4} \mathrm{~mol}\right)$ was dissolved in acetonitrile $(10 \mathrm{~mL}), \mathrm{HOBt}(0.020 \mathrm{~g}, 1.46 \times 10$ $\left.{ }^{4} \mathrm{~mol}, 1 \mathrm{eq}\right)$ was added and the reaction mixture was stirred at room temperature for 30 minutes. Then DCC $\left(0.030 \mathrm{~g}, 1.46 \times 10^{-4} \mathrm{~mol}, 1 \mathrm{eq}\right)$ was added and the mixture was stirred at room temperature for 2 hours. Separately, the previously synthesized tripeptide-coumarin conjugate $\left(0.0756 \mathrm{~g}, 1.46 \times 10^{-4}\right.$ $\mathrm{mol}$ ) was dissolved in acetonitrile $(5 \mathrm{~mL})$ and then added the reaction mixture containing Boc-Ala-OH and heated at reflux for 20 hours. The formed solid was filtered and the solvent was evaporated in a rotary evaporator. The residue was dissolved in ethyl acetate $(25 \mathrm{~mL})$ and extracted with hydrochloric acid $1 \mathrm{M}(25 \mathrm{~mL})$ and then with sodium hydrogencarbonate $10 \%(25 \mathrm{~mL})$. Anhydrous magnesium sulphate was added to the organic layer, filtered and the solvent was evaporated under reduced pressure. The residue was purified by silica gel column chromatography using dichloromethane/methanol $(50: 1)$ as eluent, the fractions containing the product were combined and evaporated, and the desired tetrapeptide-coumarin conjugate was obtained as a yellow oil $(0.0165 \mathrm{~g}$, $18 \%$ ). ${ }^{1} \mathrm{H}$ NMR (400 MHz, $\left.\mathrm{CDCl}_{3}\right): \delta=0.90-0.94\left(6 \mathrm{H}, \mathrm{m}, 2 \times \mathrm{CH}_{3}\right.$ Val), 1.34-1.39 (6H, m, $\left.2 \times \mathrm{CH}_{3} \mathrm{Ala}\right)$, $1.44(9 \mathrm{H}, \mathrm{s}, \mathrm{Boc}), 1.75-1.90\left(2 \mathrm{H}, \mathrm{m}, \mathrm{CH}_{2}\right.$ Pro), 1.98-2.05 (1H, m, $\mathrm{CH}_{2}$ Pro), 2.15-2.21 (1H, m, $\beta-\mathrm{CH}$ Val), 2.40-2.45 (1H, m, $\mathrm{CH}_{2}$ Pro), 3.51-3.66 $\left(2 \mathrm{H}, \mathrm{m}, \mathrm{CH}_{2}\right.$ Pro), $3.89\left(3 \mathrm{H}, \mathrm{s}, \mathrm{OCH}_{3}\right), 4.28(1 \mathrm{H}, \mathrm{br} \mathrm{s}, \alpha-$ $\mathrm{CH}$ Ala), 4.56-4.59 (1H, m, a-CH Val), 4.69-4.72 (2H, m, a-CH Pro), 4.77-4.81 (1H, m, a-CH Ala), $5.19(1 \mathrm{H}, \mathrm{br} \mathrm{s}, \mathrm{NH} \mathrm{Ala}), 5.30-5.36\left(2 \mathrm{H}, \mathrm{m}, \mathrm{CH}_{2}\right), 6.58(1 \mathrm{H}, \mathrm{s}, \mathrm{H}-3), 6.86-6.90(2 \mathrm{H}, \mathrm{m}, \mathrm{H}-6$ and $\mathrm{H}-8)$, $7.41(1 \mathrm{H}, \mathrm{d}, J 8.4 \mathrm{~Hz}, \mathrm{H}-5), 7.67(1 \mathrm{H}, \mathrm{d}, J 8.0 \mathrm{~Hz}, \mathrm{NH}-\mathrm{Val}) .{ }^{13} \mathrm{C} \mathrm{NMR}\left(100.6 \mathrm{MHz}, \mathrm{CDCl}_{3}\right): \delta=17.71$ $\left(\mathrm{CH}_{3} \mathrm{Ala}\right), 18.58\left(\mathrm{CH}_{3} \mathrm{Ala}\right), 18.89\left(\mathrm{CH}_{3} \mathrm{Val}\right), 19.09\left(\mathrm{CH}_{3} \mathrm{Val}\right), 25.14\left(\mathrm{CH}_{2} \mathrm{Pro}\right), 26.58\left(\mathrm{CH}_{2}\right.$ Pro $), 28.32$ $\left(\mathrm{C}\left(\mathrm{CH}_{3}\right)_{3}\right), 31.18$ ( $\left.\beta-\mathrm{CH} \mathrm{Val}\right), 46.65$ ( $\left.\alpha-\mathrm{CH} \mathrm{Ala}\right), 47.40\left(\mathrm{CH}_{2} \mathrm{Pro}\right), 50.06$ ( $\alpha-\mathrm{CH}$ Ala), $55.82\left(\mathrm{OCH}_{3}\right)$,

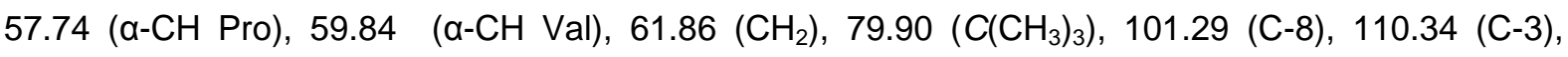
110.48 (C-4a), 112.74 (C-6), 124.37 (C-5), 148.53 (C-4), 154.86 (C8a), 155.53 (C=O Boc), 161.04 (C2), 162.95 (C-7), 170.56 ( $\mathrm{C}=\mathrm{O}$ Pro), 170.81 ( $\mathrm{C}=\mathrm{O}$ Val), 172.26 ( $\mathrm{C}=\mathrm{O}$ Ala), 172.94 ( $\mathrm{C}=\mathrm{O}$ Ala).

\section{Results and Discussion}

4-Chloromethyl-7-methoxycoumarin was obtained by a Pechmann reaction between 3methoxyphenol and ethyl 4-chloro-3-oxobutanoate, catalised by acid, in 43\% yield (Scheme 1), by a previously published procedure [8].

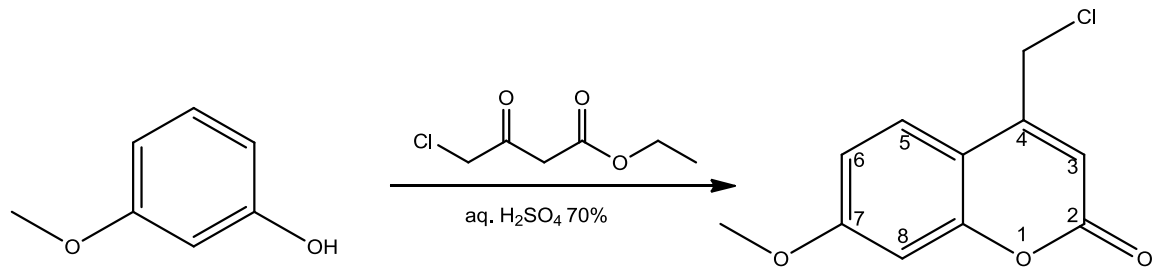

Scheme 1. Synthesis of 4-chloromethyl-7-methoxycoumarin by a Pechmann reaction. 
This compound bearing a reactive chloromethyl group was used in the derivatization of the carboxylic acid function $C$-terminal amino acid (valine) of the desired peptide in the presence of potassium fluoride. The protected ester conjugate was obtained in excellent yield $(87 \%)$ and then the $\mathrm{N}$ protecting tert-butyloxycarbonyl (Boc) group was removed by acidolysis with trifluoracetic acid, resulting in the deprotected valine-coumarin conjugate (Scheme 2).<smiles>COc1ccc2c(CCl)cc(=O)oc2c1</smiles><smiles>CC(C)C(NC(=O)OC(C)(C)C)C(=O)O</smiles><smiles>COc1ccc2c(COC(=O)C(NC(=O)OC(C)(C)C)C(C)C)cc(=O)oc2c1</smiles><smiles>COc1ccc2c(COC(=O)C(N)C(C)C)cc(=O)oc2c1</smiles>

Scheme 2. Synthesis of the valine-coumarin ester conjugate.

The coupling of the remaining amino acids was carried out with a standard DCC/HOBt coupling procedure, followed by the removal of the $\mathrm{N}$-protecting group after each coupling step (Scheme 3 ). The coumarin-labelled therapeutic tetrapeptide was obtained in the form of oil in $18 \%$ yield and charaterised by ${ }^{1} \mathrm{H}$ and ${ }^{13} \mathrm{C}$ NMR.

Coumarin derivatives are known fluorophores and the photophysical study of this tetrapetidecoumarin conjugate was made by UV-Vis and fluorescence spectroscopy in different organic solvents and mixtures with aqueous HEPES solution, in order to simulate physiological conditions. The solvents were chosen for being miscible with water (with protic and aprotic character) and the organic solvent-aqueous HEPES mixture is important for carrying out future work on the photocontrolled release of the tetrapeptide by irradiation of the fluorescent conjugate. 

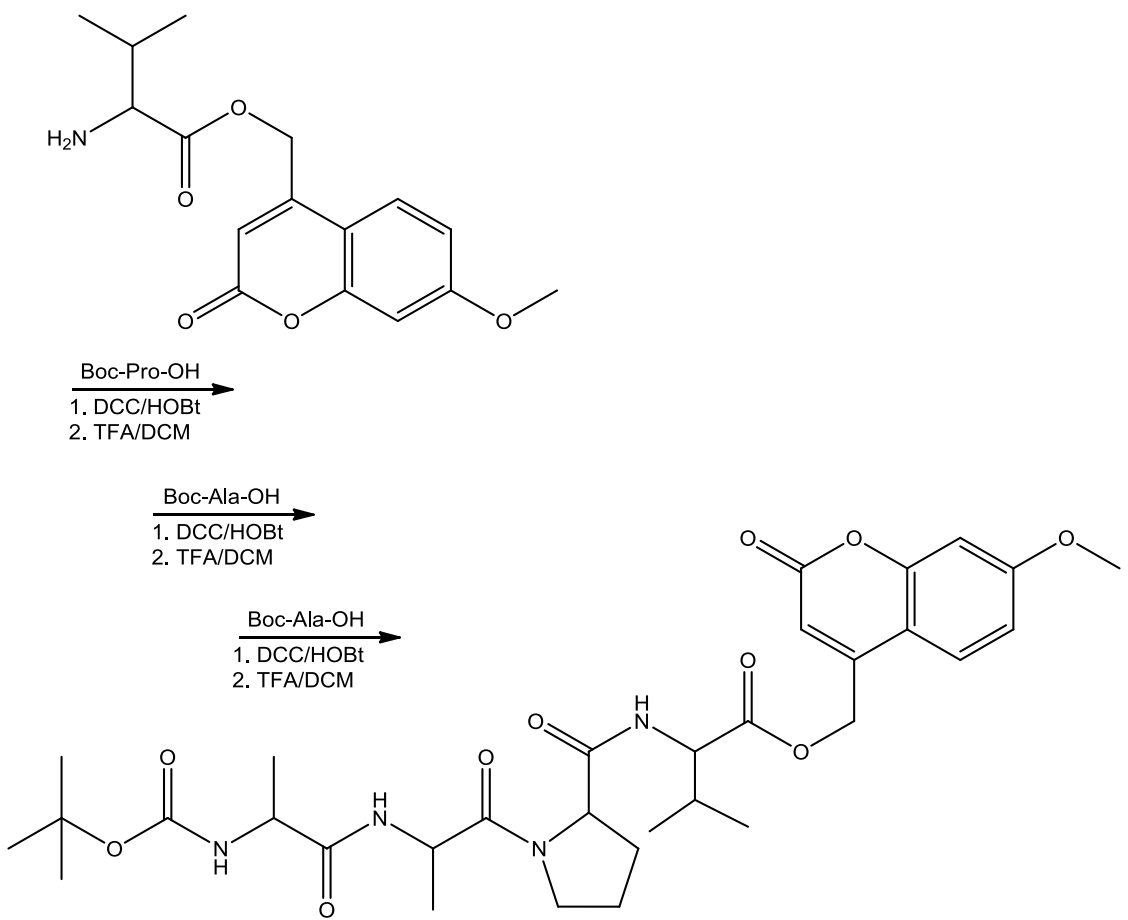

Scheme 3. Synthesis of tetrapeptide-coumarin conjugate by DCC/HOBt coupling.

The absorption and fluorescence spectra of degassed $10^{-5} \mathrm{M}$ solutions were measured and the data collected (absorption and emission maxima, molar absorptivities and fluorescence quantum yields) is presented in the Table 1. The relative fluorescence quantum yields were calculated using 9,10diphenylanthracene as standard ( $\Phi_{\mathrm{F}}=0.95$ in ethanol) [9]. For the determination of the quantum yields, the absorbance of the solutions did not exceed 0.1 and excitation was made at the wavelength of maximum absorption.

Table 1 - UV-visible absorption and emission data for the tetrapeptide-coumarin conjugate in different organic solvents and mixtures with aqueous solutions.

\begin{tabular}{cccccc}
\hline Solvent & \multicolumn{3}{c}{ UV-Vis } & \multicolumn{2}{c}{ Fluorescence } \\
& $\lambda_{\max }(\mathrm{nm})$ & $\log \varepsilon$ & $\lambda_{\mathrm{em}}(\mathrm{nm})$ & $\Phi_{\mathrm{F}}$ & $\begin{array}{c}\text { Stokes' } \\
\text { shift (nm) }\end{array}$ \\
\hline $\mathrm{EtOH}$ & 325 & 4.05 & 394 & 0.34 & 69 \\
$\mathrm{MeOH}$ & 319 & 4.11 & 399 & 0.58 & 80 \\
$\mathrm{ACN}$ & 319 & 4.24 & 393 & 0.12 & 74 \\
$\mathrm{MeOH} / \mathrm{HEPES}(80: 20)$ & 325 & 4.29 & 400 & 0.76 & 75 \\
$\mathrm{ACN} / \mathrm{HEPES}(80: 20)$ & 320 & 3.54 & 397 & 0.56 & 77 \\
\hline
\end{tabular}

By comparison of the absorption and emission maxima in the different solvents, no significant differences were observed, with values in the range $319-325 \mathrm{~nm}$ and $393-400 \mathrm{~nm}$, respectively. The 
Stokes' shift $(\Delta \lambda)$ was between 69 and $80 \mathrm{~nm}$, which is an advantageous property in fluorescence techniques, as it will minimize self-quenching phenomena.

Considering the relative fluorescence quantum yields, it was found that the tetrapetide-coumarin conjugate was more emissive in the aqueous solvent mixture by comparison of the $\Phi_{\mathrm{F}}$ in the organic solvent ( $\mathrm{MeOH}$ or $\mathrm{ACN}$ ) and in the corresponding organic solvent-aqueous HEPES buffer mixture. Overall, the fluorescence quantum yield was higher in $\mathrm{MeOH}$ or MeOH/HEPES (80:20). In Figure 1, the fluorescence spectra of the tetrapetide-coumarin conjugate in the various solvents (ca. $7.5 \times 10^{-6}$ M) are shown.

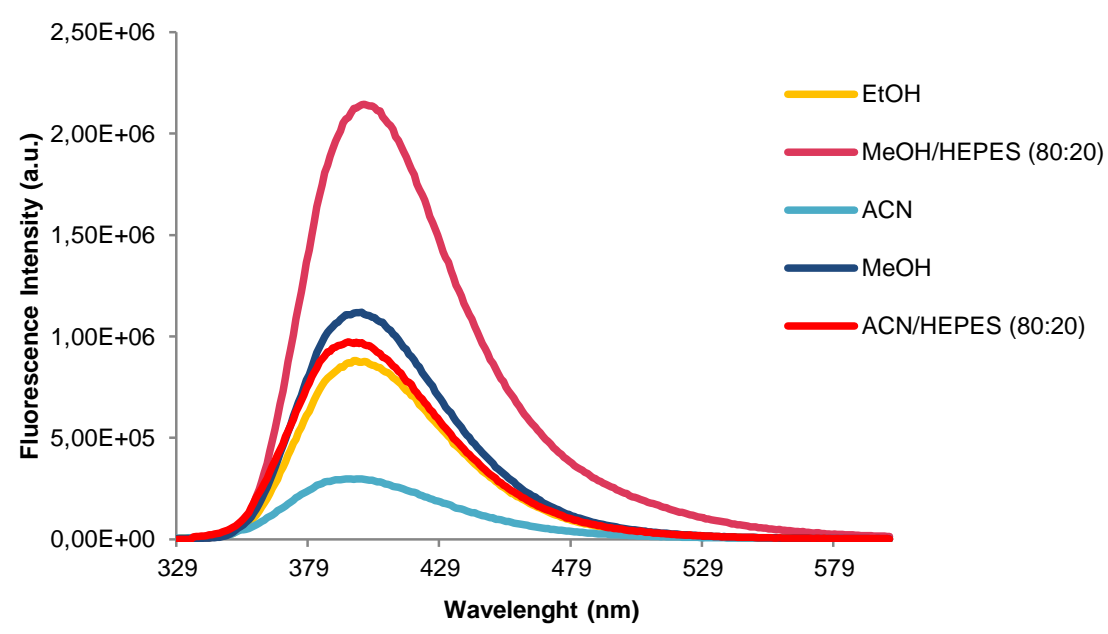

Figure 1. Emission spectra of tetrapetide-coumarin conjugate in various solvents $\left(C=7.5 \times 10^{-6} \mathrm{M}\right)$.

\section{Conclusions}

A fluorescently labelled tetrapeptide bearing a 7-methoxycoumarinyl moiety was obtained by sequential coupling. The sequence Ala-Ala-Pro-Val is of interest due to its potential as therapeutic agent for transdermal delivery for the inhibition of skin inflammatory processes. The labelling of such peptide with a fluorophore at the $C$-terminal will enable its application in fluorescence-based activity studies and in the photorelease of the active peptide from a photoactive prodrug. The photophysical study in different solvents revealed that the 7-methoxycoumarinyl moiety is an appropriate fluorogenic reagent for the derivatisation of this peptide due to the high Stokes' shifts and good to excellent fluorescent quantum yields obtained.

\section{Acknowledgements}

Thanks are due to the Fundação para a Ciência e Tecnologia (FCT, Portugal) for financial support to the NMR Portuguese network (PTNMR, Bruker Avance III 400-Univ. Minho), FCT and FEDER (European Fund for Regional Development)-COMPETE-QREN-EU for financial support to Research Centre of Chemistry, CQ/UM [PEst-C/QUI/UI0686/2013 (FCOMP-01-0124-FEDER-037302)]. 


\section{References}

[1] B. D. Wagner, Molecules 14 (2009) 210-237.

[2] B. Kovac, I. Novak, Spectrochim. Acta A 58 (2002) 1483-1488.

[3] I. Novak, B. Kovac, J. Electron. Spectrosc. Relat. Phenom. 113 (2000) 9-13.

[4] A. S. C. Fonseca, M. S. T. Gonçalves, S. P. G. Costa, Amino Acids 39 (2010) 699-712.

[5] A. S. C. Fonseca; A. M. S. Soares, M. S. T. Gonçalves, S. P. G. Costa, Tetrahedron 68 (2012) 7892-7900.

[6] R. Caccetta, J. T. Blanchfield, J. Harrison, I. Toth, H. A. E. Benson, Int. J. Pept. Protein Res. Ther. 12 (2006) 327-333.

[7] H. A. E. Benson, R. Caccetta, Y. Chen, P. Kearns, I. Toth, Lett. Pept. Sci. 10 (2003) 615-620.

[8] A. M. Piloto, A. S. C. Fonseca, S. P. G. Costa, M. S. T. Gonçalves, Tetrahedron 62 (2006) 92589267.

[9] J. V. Morris, M. A. Mahaney, J. R. Huber, J. Phys. Chem., (80) 1976, 969-974. 